

\title{
WILEY
}

\section{The Remuneration of Women's Services}

Author(s): Eleanor F. Rathbone

Source: The Economic Journal, Vol. 27, No. 105 (Mar., 1917), pp. 55-68

Published by: Wiley on behalf of the Royal Economic Society

Stable URL: http://www.jstor.org/stable/2222398

Accessed: 27-06-2016 04:37 UTC

Your use of the JSTOR archive indicates your acceptance of the Terms \& Conditions of Use, available at

http://about.jstor.org/terms

JSTOR is a not-for-profit service that helps scholars, researchers, and students discover, use, and build upon a wide range of content in a trusted digital archive. We use information technology and tools to increase productivity and facilitate new forms of scholarship. For more information about JSTOR, please contact support@jstor.org.

Royal Economic Society, Wiley are collaborating with JSTOR to digitize, preserve and extend access to The Economic Journal 


\section{THE REMUNERATION OF WOMEN'S SERVICES.}

AMONG the problems of reconstruction after the war, two at least are especially concerned with women, and they affect between them what are probably the two most important bodies of women-the industrial workers and the working-class mothers. The first is the problem of the position of women in skilled industry. The second is the question, what is to be done to safeguard the conditions under which children are born and reared, so as to ensure that the killing or maiming of so many of the best young men of the country shall not result in a permanent enfeeblement of the nation's stock. These two questions appear at first sight to have no particular connection. They are in fact, I believe, rather closely related, and though this paper is mainly concerned with the first, one of its objects is to show their inter-relation.

The war has brought about a marked change in the position of both these bodies of women. Its outbreak found the workingclass mothers mainly dependent on such portions of their husbands' wages as these husbands, belonging to every grade in the hierarchy of labour, chose to give them. This source of maintenance being withdrawn by the enlistment of the men, the women have been transformed into an army of State servants, drawing their separation allowances direct from the State in amounts proportioned, not to the value of their husbands' services, but to the size of their families. It is the largest experiment in the State endowment of maternity that the world has even seen.

In industry, the outbreak of the war found the women workers confined almost entirely, except in a few occupations traditionally their own, to the lowest, most ill-paid, and unskilled occupations. The barriers that kept them out of the skilled trades were for the most part unrecognised by law, but they were almost completely effective, being built up partly of tradition, partly of trade union regulations, but mainly of the sex exclusiveness in which employers and employed made common cause. Against these barriers the "women's movement" had beaten itself for half a century in vain, but within two years the necessities of 
the war have broken them down-by no means completely, but to such an extent that it is plain that if re-erected they will have to be based frankly upon the desire of the male to protect himself from competition, and no longer upon the alleged incapacity of the female to compete. Of course, there may be processes in which such incapacity is a fact, but in view of recent experience there is a growing tendency among employers to put such cases to the test instead of taking them for granted.

With regard to the first of these problems most people have assumed as a matter of course that at the close of the war the women who have drawn their allowances weekly at the Post Office will go back to their old condition of complete dependence upon the bounty of their husbands, the quay-porter's wife who has been keeping eight children on a separation allowance of $33 s$. being, of course, reduced to her pre-war inferiority of income to her next-door neighbour, the ship-labourer's wife, who has maintained one child on an allowance of $17 s .6 d$.

With regard to the industrial workers, the restoration of the status quo ante bellum is admittedly more doubtful. The male workers, of course, with a few enlightened exceptions, would wish it, and, so far at least as Government work is concerned, $\mathrm{Mr}$. Lloyd George, in pressing his scheme for the dilution of labour, gave certain very unqualified pledges to the trade unions which will have somehow to be redeemed. The women themselves, illorganised and voteless, with the sentiment in favour of the returning soldiers not only strong against them but strong among them, could not by themselves put up much of a fight. But they are likely to have two powerful allies : first, in the employers, who, having tasted the advantages of a great reserve of cheap, docile, and very effective labour are obviously not going to let themselves be deprived of it without a struggle; and secondly, in the growing public sense of the necessity on national grounds of making the most of our economic resources.

The more intelligent of the trade unionists are conscious of the strength of both these forces and are showing a disposition to make terms. Among the resolutions passed at the Trade Union Congress held recently was one demanding "that the conditions of female labour should be settled by the trade unions."

The implied assumption that the women themselves need not be consulted is naturally irritating, even to women who are not professed feminists. They are alarmed at the prospects of seeing their future in industry-their right to make a livelihood in the most profitable way-determined by a Parliament in which they 
have no representation, or, worse still, trafficked away as the result of a legalised bargain between employers bent on the exploitation of women and trade unionists bent on their exclusion. In the words of a manifesto issued by the National Union of Women's Suffrage Societies, they have no mind “to be treated as a football in a game between Capital and Labour with the Government acting as umpire."

In nearly all previous instances of restrictive industrial legislation the object has ostensibly been the safety and welfare of the restricted class-women or young persons or children-although it is an open secret that much of the pressure behind the legislation has had other motives. The pledges given to the trade unions in Circular No. 7 and elsewhere-that the dilution of labour shall be temporary-are probably the first instances for a century at least of Governmental interference with the right of the labourer to offer his labour in the most profitable market, based avowedly on the desire to protect a particular class of workers against competition. The success of the negotiations of which these pledges formed a part was thought necessary to the effective prosecution of the war, and no fair-minded person supposes that the Minister responsible for giving them was consciously influenced by the thought that the persons to be protected were mainly voters, and those to be excluded were nonvoters. That this is, in fact, the case is, however, an unfortunate circumstance, and the debates which took place in the House of Commons in August on the franchise question show that the Prime Minister and the leading members of the Government are well aware of this. The concession of women's suffrage would do much to put the matter on a fairer basis, to gild any pills that may have to be swallowed by women, and to prevent a renewal in an aggravated form of the stormy agitation of the years before the war.

But it would not, by itself, solve the real difficulty that lies at the root of the whole situation-a difficulty for which neither men workers nor women workers nor employers nor Parliament are to blame, but which, I venture to think, is habitually shirked by all of them, probably because of an uncomfortable fear that it is insoluble and cannot be vanquished, but only evaded by means of shifts and compromises or by pretending that it does not exist.

This difficulty may be most shortly put in the form of a question: "Is fair competition between men workers and women workers possible, bearing in mind the customary difference in the wage level of the two sexes and the causes of that customary differ- 
ence? In other words, is it possible for women to compete freely with men, without undercutting their standards of pay and so undermining their standards of life?"

The reply offered by feminists to this question is usually prompt and unhesitating, and is practically a denial of the difficulty. Women, they say, must, of course, be allowed to compete freely in all occupations. But they must not undercut. They must demand and receive equal wages for equal work. This is the claim put forward by practically all women, except, of course, when they are themselves employing women. I have not yet met the feminist whose principles compel her to pay her waitress the wages that would be demanded by a butler. The same cry has been adopted by the more astute and enlightened of the trade unionists, who see in it an effective way of maintaining the exclusion of women while appearing as the champions of equality between the sexes. It is probable that these leaders will succeed in imposing their views on their followers, though many of them are obviously rather shocked in their hearts at the idea of a woman earning a man's pay. They have a good deal of the feeling of the graduate of the London University, who in the early days of women's claim to academic privileges declared that his (pass) degree would lose all its value in his eyes if he believed that even a single woman had attained to or received a like distinction. But after the experiences of the war the cry for unconditional exclusion is likely to meet with so little sympathy that we may, I think, expect with some confidence to see women and trade unionists uniting in this claim, and Parliament possibly, unless capitalist influences are too strong, giving it legislative sanction as the easiest way out of the difficulty. It is worth while, therefore, to examine in some detail what the claim really means, how far it fits the actual conditions of social and industrial life, and how the attempt to enforce it is likely to work out in practice.

First, it must be pointed out that in adopting a formula so vague and ill-defined as "equal wages for equal work" feminists are falling into a very palpable trap. What is meant by "equal work"? That men and women are engaged on the same process in any occupation does not, of course, in itself imply equality, unless both the quality and the quantity of the output are the same. A woman who produces less than a man may be of less value to her employer, even if piece work rates are paid, because her consumption of all the standing charges of the factory-floorspace, light, heat, machinery, superintendence-is greater in proportion to her output than his. 
Even where both quality and quantity are identical it does not necessarily follow that she is an equally valuable or at least an equally acceptable employee. There are in the eyes of most employers certain standing disadvantages of women's labour which have to be reckoned with. There is the fact that the law will not allow him to work her at night nor for overtime, except under rigid restrictions; that her liability to sickness (in most trades) is rather greater; that he cannot put her to lift heavy weights or to do odd jobs; that he cannot comfortably swear at her if she is stupid ; that, in short, she is a woman, and most employers, being male, have a "club" instinct which makes them feel more at ease with an undiluted male staff. Above all, there is the overwhelming disadvantage, if the occupation is a skilled one, that she is liable to "go off and get married just as she is beginning to be of some use." 1

Of course, there are advantages which to a certain extent counter-balance these disadvantages from the employer's point of view. There is the greater docility of women; their greater willingness to be kept at routine work; their lesser liability to absence on drinking bouts, to strikes, and to other disturbances of the economic routine. But obviously most of these "advantages" are likely to be regarded by the employer rather as reasons why he can safely exploit women than as reasons why he should equitably pay them as much as men.

If the object of the claim for "equal wages for equal work" is really to secure for women a fair field of competition with men, their work being accepted or rejected on its merits, then to secure this object it seems necessary that any permanent recognised disadvantage that adheres to women workers as such should be allowed for by a pro rata rate reduction in their standard rates. The attempt to establish strict arithmetical equality between them goes further than is necessary to protect the men against unfair competition and really weights the scales against the women.

Unless this is recognised and allowed for, any bargain that is struck on the basis of "equal wages for equal work" will prove in practice the equivalent of total exclusion. It is difficult to find a

1 How seriously the last-named fact may influence the economic value of women's labour may be illustrated by the following instance, given me by the Chairman of an Education Committee, who is also an economist. At a training college for teachers of both sexes, it is estimated that the cost per head on the men's side is 50 per cent. more than the cost per head on the women's side. But "marriage mortality" among the women teachers is so great that it is reckoned that the cost of keeping up a given supply of women teachers is considerably higher to the training institution than that of the men teachers. 
modification of the formula that suits the facts, but possibly it should read "equal wages to workers of equal value."

But this does not dispose of the main obstacle to the realisation of the principle thus laid down. To understand what this is, we have to ask ourselves how it has come about that the standard of women's pay is, under normal circumstances and in the great majority of occupations, so much lower than the standard of men's pay, even when they do work which is either identical or of fully equivalent difficulty. For in this connection it is quite as relevant to compare the earnings of, say, a Court dressmaker's hands with those of a West-end tailor, as to compare those of men and women elementary teachers, though the demand for equalisation has usually been confined to the comparatively few instances of identical occupations.

The causes of the low rate of women's wages cannot be discussed in detail here, but they may be outlined. It is first necessary to make a distinction-so obvious that it ought not to need making, but which is nevertheless often ignored, between absolute and relative lowness. Women earn less than men, first, because they do, or till lately have done, chiefly the less valuable kinds of work. But they are also paid less in proportion to the value of the work they do, and that is the part of the problem which concerns us here. The reasons for the inferiority may be roughly scheduled as four.

1. Lack of trades organisation.

2. Pocket-money or supplementary wage earning.

3. A low standard of comfort.

4. A wage requirement based on individual subsistence. ${ }^{1}$

I do not propose to dwell upon the first three causes. They are obvious and easily understood, and their weight is, I believe, apt to be over-estimated rather than under-estimated. It seems better to reserve my space for a consideration of that cause which seems to me at once the most important and the most habitually under-rated, and which in default of a better name I have ventured to describe by the clumsy phrase, "A wage requirement based on individual subsistence."

In discussions on women's wages, the fact "that men have families to keep" is usually alluded to in a casual way, as though its bearing on the question were about equivalent to that of the proposition that men expect beef and beer for their dinner while

1 The reasons are fully dealt with in a paper on "The Problem of Women's Wages," published by the Liverpool Economic Society, Northern Publishing
Co., Liverpool. 
women workers are usually content with tea and pastry. Surely this is a rather astonishing instance of the extent to which familiarity can blind even intelligent observers to the significance of the most obvious facts of human life. After all, perhaps the most important function which any State has to perform-more important even than guarding against its enemies-is to secure its own periodic renewal by providing for the rearing of fresh generations. Among human beings this renewal is a much more laborious and costly process than among animals. The pre-natal period and the period of immaturity last longer. Not only do children remain economically unproductive for fifteen years, more or less, from the time of their conception, but the lives of a considerable section of the adult female community have to be entirely given over to the work of rearing, educating, and training them. All this has got to be paid for somehow. During the last forty-six years the State has taken directly upon itself the cost of the school education of its young, and it is gradually in a hesitating and halfhearted way taking over the cost of some of the minor provisions necessary for child-nurture, such as midwifery (paid for through the maternity benefit), medical attendance (through child-welfare centres, medical school inspectors, \&c.). But the great bulk of the main cost of its renewal it still pays for, as it has always done, by the indirect and extraordinarily clumsy method of financing the male parent and trusting to him somehow to see the thing through. It does not even finance him directly, but leaves it to what it is fond of calling "blind economic forces" to bring it about that the wages of men shall be sufficient for the purposes of bringing up families. The "blind forces" accomplish this task, as might be expected, in a very defective and blundering way, with a good deal of waste in some places and a much worse skimping in others, but upon the whole they do accomplish it. The wages of men in most occupations are sufficient to rear a family, not, indeed, in many of them as families ought to be reared, but without glaring violation of the man's own standards, those standards which he expects to satisfy before he marries and has children, and which the laws of supply and demand, aided by public opinion, custom, and trade organisation, enable him to enforce upon his employer. Whether he expends the wages so received upon his family or upon his own "menus plaisirs" depends, of course, entirely upon his goodwill, since the State, though it recognises in theory the rights of wife and children to maintenance, does practically nothing to enforce it; such laws as do embody this right being so imperfect and so badly carried out 
that they are next door to valueless as a protection. In the normal case, however, the family does receive the benefit of the man's wages, at least up to the point of minimum subsistence level, and the vast majority of wives and of children below fourteen are wholly or mainly maintained out of this source. In other words, the wages of the worker represent not only the value of his services to his employer, and through him to the community, but also the value of his wife's services to him and their children, and through them to the community, and, in addition, the value to the State of the children themselves. His wages, in short, are the channel by which the community, indirectly and only halfconsciously, pays for the continuance of its own existence and the rearing of fresh generations. The amount so paid becomes part of the cost of production of the commodities produced or services rendered by the trades or occupations which male workers follow, and comes eventually out of the pockets of the community as consumers.

The wages of women workers are not based on the assumption that "they have families to keep," and in so far as these wages are determined by the standard of life of the workers it is a standard based on the cost of individual subsistence, and not on the cost of family subsistence. It is perfectly true that many women workers (according to information obtained by the Fabian Women's Group, about 50 per cent. of them) contribute towards the maintenance of relations, and no doubt that fact, by making them more ambitious and anxious for money, exercises a certain upward pull upon their wages. But it must be remembered that against the influence on wages of the woman who keeps others besides herself must be set the influence of the pocket-money or supplementary wage-earners who do not even keep themselvesthe daughters living partly on their fathers, the wives working to supplement their husbands' wages, and the widows who eke out their poor relief. The number of women whose family responsibilities are really equivalent to the normal responsibilities of the average-sized household of man, woman, and three children is, after all, very smatl. Even the position of the independent widow householder is not really comparable, since the family she works for has lost its most expensive member.

If this view of the facts is correct, it would appear that the differences between the wages of men and women is a much more deep-rooted thing than is commonly supposed. It has its roots in an arrangement which to most people appears a fundamental part of the social structure, the arrangement by which the finan- 
cial responsibility for the upbringing of the family is thrown on the father. The argument that it is an indisputable principle of justice that if men and women do the same work they shall receive the same pay can be countered by the proposition, apparently equally indisputable, that if men are to pay for the upbringing of the rising generation they must be given some money to do it with. Looked at in this way, the claim of women who do not bear the same domestic burdens to receive the same remuneration seems to involve an ignoring of the still more potent claims of those wives and mothers who are rendering the most essential of all services to the State, who have to be maintained during the performance of those services, and who are at present receiving their maintenance in an indirect fashion through the wages of their husbands.

The line of argument I have been following usually either irritates or depresses all women who have the interests of their own sex at heart, because it seems to point to an impasse. If the wages of men and women are really based upon fundamentally different conditions, and if these conditions cannot be changed, then it would seem that fair competition between them is impossible, and that women are the eternal blacklegs, doomed despite themselves to injure the prospects of men whenever they are brought into competition with them and by a sort of irony of fate to undermine just those standards of family life which should be most sacred to them. If that were really so, then it would seem as if men were justified in treating women, as in practice they have treated them-as a kind of industrial lepers, segregated in trades which men have agreed to abandon to them, permitted to occupy themselves in making clothing or in doing domestic services for each other, and in performing those subsidiary processes in the big staple trades, which are so monotonous or unskilled that men do not care to claim them. The result of this treatment has been a marked growth of unrest and discontent, due as much to the consciousness of thwarted powers and undeveloped capacities as to actual suffering through underpayment and unemployment. No one who is in touch with women workers can doubt that any attempt to shut them up again in their compounds after the war will inevitably be followed by a renewal of this discontent in a much more vocal and embittered form. This is partly because their experiences during the war will have given them greater confidence in themselves and a taste for the satisfaction that is to be found in skilled, responsible, well-paid work; partly because, owing to casualties and to emigration, the propor- 
tion of the present generation of women who must remain unmarried will be considerably increased.

On the other hand, if free competition without the attempt to equalise wages is permitted, trade unionists are undoubtedly right in thinking that such competition is likely to be a much greater danger to their own standards than in the past, because the potentialities of women's labour are so much better understood by employers. These will certainly resist, and will receive a considerable measure of public support in resisting, any attempt to handicap them in their task of competing against foreign countries by cutting off from them an important source of labour supply which is open to their competitors.

No intelligent observer who reflects upon these facts can deny that the future solution of the problem is doubtful and difficult, and that it opens up unpleasant possibilities of class antagonism and sex antagonism; that for women especially it seems to offer a choice between being exploited by capitalists or dragooned and oppressed by trade unionists. It is a dismal alternative.

The most immediately practicable way of opening a door out of the difficulty would seem to be by means of one of those illogical compromises which are so dear to the British mind. The claim of women to a free entry to occupations may be conceded, subject to the condition that their labour is paid for at the same rates as male labour, and as it is obvious that they would be powerless by themselves to enforce this condition, it may receive legal sanction. This would probably involve a gigantic extension of the system of trade boards, at present confined to a few sweated trades. The practical difficulties to be overcome in securing the effective operation of such a machinery are, of course, innumerable. But they are probably not insuperable, and the plan might work fairly well as a makeshift, provided always that women with the employers' help manage to escape the almost insolently obvious trap that trade unions are already laying for them, by insisting that the rates of pay which they are permitted to accept shall be sufficiently lower than men's rates to balance, but not more than balance, the inherent disadvantages of female labour. It is true that such an arrangement ignores the distinction between the wage requirement of the two sexes, and would mean in practice securing for the woman worker a standard of living considerably more generous than could be enjoyed by male workers drawing the same wage but burdened by greater family responsibilities. But there is nothing more illogical or more unjust in that than in paying to bachelors and fathers of 
one child the same wage that is paid to the father of fourteen. The industrial woman worker has had such a cruelly hard time in the past that no woman at all events will grudge to her any windfall that may come her way.

But the arrangement is obviously a makeshift without finality. If wages are to be regulated by the State, who can suppose that its interference will be limited to those trades where both sexes work? Obviously this would give the employer the strongest inducement to eliminate one sex or the other, so as to be free from control. If State regulation is extended to all trades, upon what is the standard laid down to be based? Can one justify levelling up women's wages to men's in trades where they both work, while keeping them on an altogether lower scale in wholly feminine trades of equivalent difficulty?

Is there not a more excellent way? The one thing that might conceivably reconcile the woman worker to a continuance of the present limitations upon her industrial opportunities, to meagre earnings and to monotonous work, would be the belief that her sacrifice was a necessary part of a social system upon which the maintenance of family life, the welfare of future generations, depend. For, after all, the majority of women workers are only birds of passage in their trades. Marriage and the bearing and rearing of children are their permanent occupations. But when we turn our eyes from the industrial world to the homes of the workers, is the spectacle of what we find there one that arouses much enthusiasm for the preservation of the existing order? The arrangement by which the most fundamental necessity of the State, the necessity for its own reproduction, is left to haphazard individual effort is so ancient and universal that most people never think of questioning it. But in this, as in other spheres, the war has taught us that, where national interests are at stake, goas-you-please methods may be too dearly paid for. There is so much futile prattle about child-welfare and the subject is so attractive to sentimentalists and amateurs that the real student tends to shy away from it. But the question of child supply, its quantity and quality, is surely at least as well worth serious consideration as the question of wheat supply. Can anyone who thinks about it seriously defend the system which makes the remuneration of all the services connected with that most important supply dependent upon and subsidiary to the remuneration of a quite different and irrelevant set of services, those of the industrial workers? Consider what happens in the average workingclass family.

No. 105.-VoL. Xxvir. 
The wage-earning capacity of a man in the unskilled and the less skilled trades and in all occupations mainly dependent on physical force, reaches its maximum when he is still quite young, often before he is married. As a bachelor his income affords an ample margin for his pleasures. When he marries, what has sufficed for one has to suffice for two; as children come, it has to suffice for three, four, five, for as many children as he chooses to have. This has several alternative results, all of them bad. At the best, husband and wife restrict more and more closely their personal expenditure, till all but bare necessities have been given up. As each child is born, a bit is pinched off the share of its elders in order to make a portion for the newcomer. If the husband is selfish, it is the wife and children who do all the pinching. In an assembly of married working women one can usually pick out at a glance which is the mother of a first baby. She is well clad and comely ; the baby kept "like a little prince." As the claims on her money and time increase, her standard must be lowered. The home is less well kept, the children are worse fed, worse clad, and worse disciplined. She herself becomes anxious and haggard or coarsened and indifferent. There are miracle-working members of large families of whom all this is untrue, but they are a minority.

Those married couples who are cautious and self-regarding meet the difficulty in another way: by restricting the number of their children. The rapid growth in the practice of limiting families has attracted much public attention lately, but its quantitative effect is not the most serious. It seems quite plain that while the upper middle and upper working classes are practising rigid restriction, the strata below them, including the whole slum population, are multiplying as freely as ever, while the health authorities combined with private benevolence do just enough to keep the slum babies alive, but not enough to keep them healthy. Hence we are as a nation recruiting the national stock in increasing proportion from those who have sunk into the lowest strata because they are physically, mentally, or morally degenerate.

Even in the normal household, therefore, when wife and children get their fair share of the husband's wage, there is no guarantee that that share is adequate for healthy maintenance, and the system seems irrational. Pharaoh compelled the Israelites to make bricks without straw, but even he did not double the quota of bricks exacted each day without allowing any increase in the supply of clay. 
The worst feature of the system, however, is that it provides no guarantees that wife and children shall receive their fair share of the wage which the husband earns nominally in respect of his own exertions alone, though really, if the reasoning of this paper be correct, upon the hypothesis of their existence. Law and custom encourage him in the belief that the money is his own, and Englishmen are strong in the conviction that a man has a right to do what he likes with his own. Unless he carries neglect so far as to bring upon himself the attentions of the S.P.C.C. or to provoke his wife to demand a separation, he is subject to no pressure even from public opinion, and as selfishness and selfindulgence are tolerably common failings in all classes, the proportion of families where this freedom is abused, though no doubt it represents a minority of the population, is still an exceedingly substantial minority.

All experienced social workers and all persons whose professional work brings them into intimate contact with the homes of the people know how much of the premature old age, the chronic anæmia and ailments of the women, the mal-nutrition and physical or mental degeneracy of the children, is due to this cause.

Many observers, while admitting the defects of the present system, appear to think that any attempt to disturb it, to relieve men from the financial responsibility of the maintenance of their families, or to release wives from total dependence on their husbands, would undermine parental affection and destroy the sanctity of family life. It may, however, be doubted whether the bonds between parents and children, husbands and wives, are really dependent to any considerable extent upon the financial relations between them. There seems no reason to suppose that the custom of marriage settlements in the middle and upper classes injures the marital relation, while there can be no doubt, I think, in the minds of any who have had much to do with married women of the working-class, that friction about money and bitter resentment when they are unable to satisfy the needs of their children because of the selfishness or thoughtlessness of their husbands have in many of them effectually destroyed affection very early in their married lives. During the war many of these women have tasted for the first time the sense of security, of ease and dignity that comes from the enjoyment of a settled income, proportioned to the size of their families and paid directly to themselves. It will be interesting to see how, when the war is over, they will take the restoration of pre-war conditions. It 
is not pleasant to reflect how many prototypes there are of the two women in Punch who "did not think the war would last long; it was too good to last." Let every man who blames them imagine what it would be like to be absolutely dependent upon the whim of one human being, not only for every penny which he spent on himself, but for all the tools and materials for carrying out his work in life.

It is outside the scope of the present article to consider what should be the basis, the scale, and the machinery of any system by which the State should take upon itself the prime cost of rearing future generations. It might be done through a continuance of something resembling the present system of separation allowances, which provides for the upkeep of individual homes. The allowance might be on a flat rate-so much for the woman and so much for each child; or it might be dependent to some extent on the amount of the allotment made by the man from his pay. Or, again, our system of elementary schools might be developed into day boarding-schools, where children were fed and clad as well as taught, and could enjoy organised play. In the upper and middle classes, practically every parent who can afford it either commits his children to such schools or sends them altogether away from home. Yet it is commonly assumed that the discipline of the ordinary working-class home and the playground of the streets are sufficient for the working-class child, and when the results are bad the over-driven mother is blamed.

Whatever system were adopted, it is probable that a large proportion of the husbands would desire to supplement the Government provision, and consequently "having families to keep" would still exert an upward pull on the wages of men as compared with those of women. The potentialities of individual spending are for both sexes so great that it is pretty certain that both would continue to struggle for as high wages as they could get, and would invoke all the resources of trade unionism and political influence to enforce their claims. But the main reason for the differentiation in wages between the two sexes having disappeared, competition between them that was at once free and fair would be for the first time possible, and the services of women-not only in industry, but in the home-would be remunerated on their merits.

Eleanor F. Rathbone 